\title{
NUTRITIONAL AND SENSORY ANALYSES OF WHEAT-UNRIPE PLANTAIN COMPOSITE FLOUR ON BREAD MAKING
}

\author{
Christopher J. Etti, Victoria G. Ekanem \\ Department of Agricultural and Food Engineering, Faculty of Engineering, \\ University of Uyo, Uyo, Akwa Ibom State, Nigeria
}

\begin{abstract}
This study analyzes the nutritional and sensory properties of wheat- and unripe plantain composite flour having a mix ratio of $70: 30,80: 20,90: 10$ and 100:0 respectively, with 100:0 ratio mix serving as the control. Unripe plantain flour was selected due to its high iron content which can solve dietary concerns encountered by anaemic and celiac patients because of low iron and high protein (gluten) content in wheat bread. The nutritional analysis of the composite flour such as ash, lipid, fibre, carbohydrate, protein, moisture content and iron contents of the mixed flour were determined. Physical properties of the composite bread were determined: loaf weight, loaf volume, loaf height, and loaf specific volume.The incorporation of plantain flour into baking bread became effective because it is economical, better supplies essential nutrients such as iron and protein to humans, and a better overall use of domestic agricultural products such as plantain.Incorporation of higher amount of unripe plantain flour increased loaf weight with a corresponding reduction in specific volume of the bread, which affected the bread making process. It was concluded that organoleptically acceptable bread could be formulated from wheat-unripe plantain composite flours using up to 70:30 mix ratio as maximum acceptable levels of substitution for bread making.
\end{abstract}

Keywords - Wheat-unripe plantain composite flour, bread, loaf specific volume, proximate composition, iron content

\section{INTRODUCTION}

Bread is the result of baking the dough obtained from a mixture of flour, salt, sugar, yeast and water by a chain of processes that comprises mixing, kneading, proofing, shaping and baking according to Mebpa et al. (2007). Additional ingredients like fats, milk, milk-solids, sugar, egg, and antioxidants may be added. Bread is a vital staple food with steady and increasing consumption in Nigeria. It is the most popular among all wheat-based products such as biscuits, cakes, doughnuts, chin-chin, cookies, etc. (Badifu, 2005). It is sometimes not so cheap for an average Nigerian due to the fact that it comes from wheat flour which has to be imported into the country. For this reason, the use of composite flours have been greatly encouraged to decrease the demand for imported wheat flour and make the food available to low income earners and also reduce the amounts of wheat being consumed per head (Giami, 2004). Although there now exist a substantial amount of available composite bread technology, such bread still require at least $70 \%$ of wheat flour to be able to rise (Eggleston, 1992). The predominance of wheat flour for baking of leavened bread is due to the properties of its elastic gluten protein, which helps in producing a relatively large loaf volume with a regular crumb structure. Moreover, only wheat flour dough is capable of retaining gas during proof and baking, and therefore forms a typical aerated foam structure as bread. Other cereals contain similar protein groups, but gasholding capacity is limited. Although all leavened cereal dough produce gas $\left(\mathrm{CO}_{2}\right)$ during proof, wheat dough retains gas much longer even at high temperatures than other cereal flour dough (Hoseney, 1991). Wheat gluten is made up of a mixture of two groups of protein: gliadins and glutenins, which gives different contributions to the viscoelasticity of gluten. The importance of gluten in bread-making cannot be underestimated therefore, wheat flour can only be supplemented with other flours for bread making to improve its nutritional quality, as each flour retain its nutritional value and such bread is also recommended for people with inability to digest gluten (celiac disease).

Unripe plantain is traditionally processed into flour in Nigeria and in other West and Central African countries (Ukhum, 1991). It is however gradually finding applications in weaning food formulation and composite flour preparations in line with Ogazi et al. (1996) and Mepba et al. (2007). Plantain is a popular dietary staple food due to its versatility and good nutritional value. Unripe plantain fingers are valuable sources of iron and fibre to the body in contrast to the ripe variety which are invaluable source of carbohydrate, comparable in nutritive value to yam or potato, and are useful as a variant on the usual staple foods. Unripe plantain is used to produce plantain flour, since it has high starch content of about $35 \%$ on wet weight basis (Simmond, 1976).

Wheat flour can be fortified with unripe plantain flour because of high iron content of unripe plantain flour in contrast to the 


\section{International Journal of Engineering Applied Sciences and Technology, 2021 \\ Vol. 5, Issue 9, ISSN No. 2455-2143, Pages 83-87 \\ Published Online January 2021 in IJEAST (http://www.ijeast.com)}

ripe plantain which is low in iron but high in carbohydrates. Anemic patients require a constant supply of blood to their system whether whole or part. Therefore, their nutrition should be able to supply blood to their body system. Bread fortified with unripe-plantain flour is recommended for this class of people as well as for vegetarians whose nutrition should contain fewer amounts of sugars.

Wheat-unripe plantain composite flour bread with $30 \%$ substitution and below were analyzed in this study to understudy the nutritional characteristics of the flour, physical properties of the bread loaves, as well as sensory analysis and acceptability of the bread.

\section{MATERIALS AND METHODS}

\section{A. Materials}

Commercially available all-purpose wheat and plantain flours, table salt, and granulated sugar (manufactured by Dangote Group Nigeria Ltd., Lagos, Nigeria) used were purchased from Nteps Shopping Mall in Uyo, Akwa Ibom State, Nigeria. Butter, dry baker's yeast and milk were obtained from Akpan andem Main Market, Uyo, Akwa Ibom State, Nigeria.

\section{B. Flour Analysis}

Analysis of flour was conducted on the composite flour made from different combinations of wheat flour and unripe plantain flour at ratios of 0:100, 90:10, 80:20, 70:30 and 100:0, respectively.

\section{Moisture Content}

The moisture content of the flour was determined with the use of a digital moisture analyzer (OHAUS MB45, UK) set at $105^{\circ} \mathrm{C}$. The flour was weighed to $3.0 \mathrm{~g} \pm 0.01 \mathrm{~g}$ in a sample plate and measurements were made in triplicate. The moisture analyser was allowed to cool between tests for each powder.

\section{$D$. Bread Production by the Straight Dough Method}

The straight dough method was used to prepare the bread. This method involves the addition of all the ingredients (flour, salt, water, sugar, yeast, etc.) at mixing stage and kneading same to obtain the dough (Gisslen, 2012). The different dough samples made from different ratios of wheat : unripe plantain flour were placed in baking pans smeared with butter and covered with poly-ethene for the dough to ferment resulting in gas production and gluten development enabling the dough to rise for about an hour as this shows the swelling power of the dough. The dough was then baked in an oven at $230^{\circ} \mathrm{C}$ for 30 minutes. The baked loaves were removed from the pans and allowed to cool for analysis.

\section{E. Proximate Composition}

Proximate composition of the samples were carried out using official AOAC (1984) methods for moisture content, crude fat, crude fibre, ash, crude protein. A nitrogen-to-protein conversion factor of 6.25 was used. Carbohydrate content was calculated by difference.

\section{$F$. Iron Content}

The iron content of the bread was determined by using the bread ash earlier used. The ash was placed in porcelain crucibles, then a few drops of distilled water were added, followed by $2 \mathrm{ml}$ of concentrated $\mathrm{HCl}$. $10 \mathrm{ml}$ of $20 \% \mathrm{HNO}_{3}$ was added, then evaporated on a hot plate. The samples were then filtered through a Whatman filter paper into a $100 \mathrm{ml}$ volumetric flask. The mineral element, iron, was determined by an atomic absorbance spectrophotometer (AOAC, 2005).

\section{G. Bread Quality Analysis}

After cooling, the bread samples were weighed using a digital analytical weighing balance. The loaf volume was measured by seed displacement method (Giami, 2005), using millet grains. The bread sample $(5 \mathrm{~g})$ was placed in an empty graduated cylinder $(100 \mathrm{ml})$ and filled with the millet grains. The cylinder was slightly tapped to ensure that the grains were properly packed. The level of the packed millet grains containing the bread sample in the volumeter was noted and recorded. The bread sample was removed from the volumeter leading to a drop in height of the millet grains. The new level of the millet grain was also noted and recorded. The loaf volume was determined by the difference between the level of the packed millet grains containing the bread sample and the level of the millet grains after the bread sample had been removed:

Loaf volume $=H_{0}-H_{1}$

Where:

$H_{0}=$ height of millet grains with bread sample.

$H_{1}=$ height of millet grains after the bread was removed.

\section{H. Specific Volume}

Specific volume (in $\mathrm{ml} / \mathrm{kg}$ ) was obtained by dividing the loaf volume $(V)$ of the bread by its corresponding loaf weight $\left(w_{t}\right)$. Thus,

$$
\text { Specific volume }=V / w_{t}
$$

After moulding, the height of the dough was measured using a meter rule. After baking, the bread samples' heights were also measured and recorded. 


\section{International Journal of Engineering Applied Sciences and Technology, 2021 \\ Vol. 5, Issue 9, ISSN No. 2455-2143, Pages 83-87 \\ Published Online January 2021 in IJEAST (http://www.ijeast.com)}

\section{Sensory Evaluation}

The four bread samples were coded and presented to a semitrained panel for sensory evaluation (Ihekoronye and Ngoddy, 1985). The panelists scored the aroma, taste, texture, crust colour, crumb colour, appearance and general acceptability of the bread using a 9 point hedonic scale, where 9 indicates "extremely like" and 1 indicates "extremely dislike".

\section{J. Statistical Analysis}

All analytical determinations were conducted in triplicates such that means and standard deviations were calculated. The data obtained were subjected to analysis of variance (ANOVA), to assess the properties of the flour and compute their data using Graph Pad Prism 5.0 software (Graph Pad Software Inc., La Jolla, CA, USA). Means were separated by calculating the least significant difference (LSD) at $(\mathrm{P} \leq 0.05)$.

\section{RESULTS AND DISCUSSION}

\section{A. Nutritional Analysis}

The nutritional composition of the composite flours is presented in Table 1. The results showed an increase of ash content in the composite flour samples per increase in plantain flour. The highest ash content was recorded in composite flour of 0:100 (wheat flour : unripe plantain) which was 3.36 $( \pm 0.01) \%$, showing that plantain flour has more ash content than wheat flour. This result is in agreement with the investigations of Ahmad et al. (2001) where low ash content was reported in the quality characteristics of different wheat varieties grown in Pakistan. Ash content is a reflection of the mineral matter in a food sample (Iwe et al., 2017). High ash content in plantain flour suggests it contains high mineral matter.

Table 1.Nutritionalcomposition of the flours

\begin{tabular}{|c|c|c|c|c|c|c|c|}
\hline $\mathbf{X}$ & $\begin{array}{l}\text { Ash } \\
(\%)\end{array}$ & $\begin{array}{l}\text { Lipid } \\
(\%)\end{array}$ & $\begin{array}{l}\text { Fibre } \\
(\%)\end{array}$ & $\begin{array}{l}\text { Carboh } \\
\text { ydrate } \\
(\%)\end{array}$ & $\begin{array}{l}\text { Protein } \\
(\%)\end{array}$ & M. C & $\begin{array}{l}\text { Iron } \\
(\mathrm{mg} / \mathrm{l})\end{array}$ \\
\hline $100: 0$ & $\begin{array}{l}1.46 \\
\pm 0.11^{\mathrm{e}}\end{array}$ & $\begin{array}{l}2.70 \\
\pm 0.11^{\mathrm{e}}\end{array}$ & $\begin{array}{l}2.80 \\
\pm 0.11^{\mathrm{e}}\end{array}$ & $\begin{array}{l}73.68 \\
\pm 0.02^{\text {e }}\end{array}$ & $\begin{array}{l}13.26 \\
\pm 0.01^{\mathrm{a}}\end{array}$ & $\begin{array}{l}6.1 \\
\pm 0.2^{d}\end{array}$ & $\begin{array}{l}2.72 \\
\pm 0.14^{\mathrm{e}}\end{array}$ \\
\hline 90:10 & $\begin{array}{l}2.18 \\
\pm 0.11^{d}\end{array}$ & $\begin{array}{l}3.00 \\
\pm 0.11^{d}\end{array}$ & $\begin{array}{l}5.09 \\
\pm 0.04^{\mathrm{d}}\end{array}$ & $\begin{array}{l}74.15 \\
\pm 0.03^{d}\end{array}$ & $\begin{array}{l}8.33 \\
\pm 0.12^{b}\end{array}$ & $\begin{array}{l}7.3 \\
\pm 0.2^{\mathrm{c}}\end{array}$ & $\begin{array}{l}8.53 \\
\pm 0.13^{d}\end{array}$ \\
\hline $80: 20$ & $\begin{array}{l}2.58 \\
\pm 0.11^{c}\end{array}$ & $\begin{array}{l}3.50 \\
\pm 0.11^{c}\end{array}$ & $\begin{array}{l}5.52 \\
\pm 0.11^{\mathrm{c}}\end{array}$ & $\begin{array}{l}74.60 \\
\pm 0.02^{\mathrm{c}}\end{array}$ & $\begin{array}{l}6.15 \\
\pm 0.10^{c}\end{array}$ & $\begin{array}{l}7.7 \\
\pm 0.9^{b}\end{array}$ & $\begin{array}{l}9.63 \\
\pm 0.11^{\text {c }}\end{array}$ \\
\hline $70: 30$ & $\begin{array}{l}2.80 \\
\pm 0.11^{b}\end{array}$ & $\begin{array}{l}3.65 \\
\pm 0.11^{b}\end{array}$ & $\begin{array}{l}5.82 \\
\pm 0.00^{b}\end{array}$ & $\begin{array}{l}75.28 \\
\pm 0.00^{b}\end{array}$ & $\begin{array}{l}4.65 \\
\pm 0.03^{d}\end{array}$ & $\begin{array}{l}7.8 \\
\pm 0.3^{b}\end{array}$ & $\begin{array}{l}9.74 \\
\pm 0.04^{b}\end{array}$ \\
\hline $0: 100$ & $\begin{array}{l}3.36 \\
\pm 0.01^{\mathrm{a}}\end{array}$ & $\begin{array}{l}3.80 \\
\pm 0.11^{\mathrm{a}}\end{array}$ & $\begin{array}{l}6.51 \\
\pm 0.11^{\mathrm{a}}\end{array}$ & $\begin{array}{l}76.03 \\
\pm 0.02^{\mathrm{a}}\end{array}$ & $\begin{array}{l}2.30 \\
\pm 0.03^{\mathrm{e}}\end{array}$ & $\begin{array}{l}8.0 \\
\pm 0.2^{\mathrm{a}}\end{array}$ & $\begin{array}{l}12.00 \\
\pm 0.15^{\mathrm{a}}\end{array}$ \\
\hline
\end{tabular}

Note: The experiment was done in triplicate and the data are expressed as mean \pm standard deviation, different superscripts within each nutrient composition differ significantly at $(P<0.05)$. $\mathrm{X}=$ Wheat: unripe plantain flour ratio, $\mathrm{M} . \mathrm{C}=$ moisture content (dry basis)
The lipid content showed an increase per substitution of more plantain flour, with the lipid content increasing by up to $35 \%$ when plantain flour used was increased to $30 \%$. The highest lipid content was recorded in $100 \%$ of plantain flour. This reveals that wheat flour has less lipid content than plantain flour. Besides, the fibre content of unripe plantain contained the highest fibre value $(6.51 \pm 0.11 \%)$ while the wheat flour had the lowest fibre content $(2.80 \pm 0.11 \%)$, indicating plantain flour is high in fibre. Consequently, there was an increase in fibre content with the increase of plantain flour substitutions. The carbohydrate content showed an increased with substitutions of more plantain flour. The protein content for $100 \%$ wheat flour with a value of $13.26 \%$ was remarkably massive, but there was a sharp decrease in protein content for $100 \%$ unripe plantain flour with a value of $2.30 \%$. A decrease in protein content with substitutions of more plantain flour is sufficiently good to recommend it for bread making. This is because it can be used to substitute part of the wheat flour in bread making as celiac patients do not require much protein from high gluten contents bread as reported by Adegunwa et al. (2017). In addition, the result of moisture content did not significantly influence the flowability of the composite flours (see Table 1) as the moisture content was low, ranging from $6.1( \pm 0.2) \%$ of $100: 0$ wheat-unripe plantain composite flours to $8.0( \pm 0.2)$ of $0: 100$ of wheat-unripe composite flours. Increasing moisture content may make flour not free flowing (cohesive); however, exceeding certain moisture contents the moisture may act as lubricant thus improving the flour (powder) flowability (Mohsenin, 1986).

The iron content of the composite flour is shown in Table 1. The highest iron content was recorded in $100 \%$ unripe plantain flour which was about $12.00 \mathrm{mg} / \mathrm{l}$. Meanwhile, the lowest value of iron content was found in $100 \%$ wheat flour, which was about $2.72 \mathrm{mg} / \mathrm{l}$. This result suggests that plantain flour can be a good source of iron, and incorporation of plantain flour in bread making might improve the iron content in the bread. It also reveals that increase in the amount of plantain flour in the mix ratio increased the iron contents of the flour. This favours anaemic patients as consumption of bread made from plantain flour as a wheat flour substitute might help to improve their blood levels.

Table 2.Physical properties of the bread loaves

\begin{tabular}{lllll}
\hline $\begin{array}{l}\text { Wheat: } \\
\text { unripe } \\
\text { plantain } \\
\text { flour }\end{array}$ & $\begin{array}{l}\text { Loaf } \\
\text { weight } \\
(\mathbf{g})\end{array}$ & $\begin{array}{l}\text { Loaf } \\
\text { volum } \\
\mathbf{e}(\mathbf{m l})\end{array}$ & $\begin{array}{l}\text { Loaf } \\
\text { height } \\
(\mathbf{m m})\end{array}$ & $\begin{array}{l}\text { Specific } \\
\text { volume } \\
(\mathbf{m l} / \mathbf{g})\end{array}$ \\
\hline $100: 0$ & 110.00 & 9.00 & 104.00 & 0.082 \\
& \pm 0.001 & \pm 0.001 & \pm 0.000 & \pm 0.001 \\
$90: 10$ & 170.00 & 7.00 & 79.00 & 0.041 \\
& \pm 0.001 & \pm 0.002 & \pm 0.001 & \pm 0.001 \\
$80: 20$ & 179.00 & 6.00 & 74.00 & 0.034 \\
& \pm 0.005 & \pm 0.000 & \pm 0.000 & \pm 0.002 \\
$70: 30$ & 189.00 & 5.50 & 70.00 & 0.029 \\
& \pm 0.003 & \pm 0.005 & \pm 0.000 & \pm 0.003 \\
\hline
\end{tabular}




\section{International Journal of Engineering Applied Sciences and Technology, 2021 \\ Vol. 5, Issue 9, ISSN No. 2455-2143, Pages 83-87 \\ Published Online January 2021 in IJEAST (http://www.ijeast.com)}

The loaf weight for wheat-unripe plantain flour ranged from $170 \mathrm{~g}$ (for 90:10 mix ratio, as the lowest) to $189 \mathrm{~g}$ (for 70:30 mix ratio, as the highest) weight, while 100:0 (control bread) weighed $110 \mathrm{~g}$. This revealed that increasing substitutions of plantain flour in bread increased its weight as shown in Table 2.

The loaf volume ranged from $7 \mathrm{ml}$ (for 90:10 mix ratio wheatunripe plantain flour, as the highest)to $5.5 \mathrm{ml}$ (for 70:30 mix flour, as the lowest), while 100:0 mix was $9 \mathrm{ml}$ as the highest loaf volume as calculated from equation (1). This showed that increasing substitutions of plantain flour in bread reduced its loaf volume as shown in Table 2. The loaf height ranged from $70 \mathrm{~mm}$ as the lowest to $104 \mathrm{~mm}$ as the highest, showing that inclusion of plantain flour in bread reduced its loaf height. The loaf volume and loaf height revealed a decrease with substitution of more plantain flour because of the decrease in the amount of gluten to react with the yeast during the proofing time, while increasing its loaf weight. The specific volume of the bread loaves decreased with increase in plantain flour substitution as also seen from Table 2.

Bread samples were subjected to a panel of 10 semi-trained judges comprising males and females using a 9-point hedonic scale of different eating habits. Sensory attributes namely aroma, taste, texture, crumb colour, crust colour, appearance and general acceptability are shown in Table 3. The sensory data for colour scores of composite flour bread and wheat flour bread (as control) are presented in Table 3. The highest score for crumb colour was awarded to $90: 10 \mathrm{mix}$ ratio of wheat-unripe plantain flour (6.30), which was not significantly different at $(\mathrm{P} \leq 0.05)$ from bread of $100 \%$ wheat flour of 7.30 score followed by sample 80:20 (5.6) and sample 70:30 (4.8), which was the lowest.

Table -3.Sensory attributes of composite flour bread

\begin{tabular}{lllllll}
\hline $\mathrm{X}$ & Aroma & Taste & Texture & $\begin{array}{l}\text { Crust } \\
\text { colour }\end{array}$ & $\begin{array}{l}\text { Crumb } \\
\text { colour }\end{array}$ & $\begin{array}{l}\text { General } \\
\text { acceptance }\end{array}$ \\
$100: 0$ & 7.60 & 7.50 & 7.30 & 7.20 & 7.30 & 7.60 \\
& $\pm 0.03^{\mathrm{a}}$ & $\pm 0.15^{\mathrm{a}}$ & $\pm 0.11^{\mathrm{a}}$ & $\pm 0.13^{\mathrm{a}}$ & $\pm 0.08^{\mathrm{a}}$ & $\pm 0.14^{\mathrm{a}}$ \\
$90: 10$ & 7.20 & 5.40 & 7.30 & 6.60 & 6.30 & 7.10 \\
& $\pm 0.01^{\mathrm{a}}$ & $\pm 0.19^{\mathrm{b}}$ & $\pm 0.17^{\mathrm{a}}$ & $\pm 0.07^{\mathrm{b}}$ & $\pm 0.18^{\mathrm{a}}$ & $\pm 0.16^{\mathrm{a}}$ \\
$80: 20$ & 5.30 & 4.70 & 5.60 & 5.60 & 5.60 & 5.10 \\
& $\pm 0.01^{\mathrm{b}}$ & $\pm 0.20^{\mathrm{c}}$ & $\pm 0.08^{\mathrm{b}}$ & $\pm 0.07^{\mathrm{c}}$ & $\pm 0.09^{\mathrm{b}}$ & $\pm 0.06^{\mathrm{b}}$ \\
$70: 30$ & 4.40 & 3.50 & 4.60 & 5.10 & 4.80 & 4.30 \\
& $\pm 0.04^{\mathrm{c}}$ & $\pm 0.09^{\mathrm{d}}$ & $\pm 0.13^{\mathrm{c}}$ & $\pm 0.16^{\mathrm{d}}$ & $\pm 0.15^{\mathrm{c}}$ & $\pm 0.10^{\mathrm{c}}$ \\
\hline
\end{tabular}

Note: The experiment was done in triplicate and the data are expressed as mean \pm standard deviation, different superscripts within each sensory attributes differ significantly at $(P<0.05)$. X= Wheat: unripe plantain flour ratio.

The crust colour of the bread followed a similar trend as the crumb colour. Generally, the study revealed that colour scores decreased with increase in incorporation of plantain flour. The desired colour of bread is obtained mainly due to the Maillard browning during baking. Highest aroma and textures scores were obtained for bread made from 90:10 wheat-unripe plantain flour (7.20 and 7.30 respectively); this result was not significantly different at $(\mathrm{P} \leq 0.05)$ from bread of $100 \%$ wheat flour with regards to aroma and textures respectively. The aroma, texture and taste scores decreased rapidly with increase in amounts of plantain flour as seen from Table 3 .

In terms of general acceptance, both 90:10 wheat-unripe plantain flour bread and $100 \%$ wheat bread were accepted with no significant difference at $(\mathrm{P} \leq 0.05)$. This was followed by $80: 20$ composite (5.10) and then 70:30 (4.30) mix ratios of wheat-unripe plantain flour. The general acceptance scores may also be affected by the age group of the taste panelists as older people are seen to prefer bread with higher unripe plantain flour due to nutritional advantages.

\section{CONCLUSION}

The substitution of wheat flour with some level of unripe plantain flour in bread making was carried out. The addition of unripe plantain flour to wheat flour improved the nutritional composition of the composite flour. The addition of unripe plantain flour also improved the iron content of the bread. Substitution of wheat flour with some level of unripe plantain flour affected the physical properties of the bread such as loaf weight, loaf volume, loaf height and the loaf specific volume as the gluten content of the dough was affected. Increasing levels of plantain flour in bread making was found to result in a decrease in the loaf volume, loaf height, and loaf specific volume. The sensory analysis revealed that 90:10 wheatunripe plantain flour bread was generally accepted with regards to aroma, texture and crumb colour, with no significant difference from $100 \%$ wheat flour bread.

\section{REFERENCE}

1. Adegunwa, M. O., E. O. Adelekan., A. A. Adebowale., H. A. Bakare and E. O. Alamu. 2017. Evaluation of nutritional and functional properties of plantain ( Musaparadisiaca L.) and tigernut

(Cyperusesculentus L.) flour blends for food formulations. Cogent Chemistry, 3, 1-15.

2. Ahmad, I., F. M. Anjum and M. S. Butt. 2001. Quality characteristics of wheat varieties grown from 1933-1996. Pakistan Journal of Food Sciences, 11, $1-17$.

3. AOAC. 1984. Official methods of analysis. Association of official analytical chemists.14th Edn.The William byrd Press, Richmond, VA., USA.

4. AOAC. 2005. Official methods of analysis. Association of official analytical chemists.18th Edn.Arlington, V. A. Association of official Analytical Chemist.806-842.

5. Badifu, G. I. O. 2005. Influence of mango mesocarp flour supplement to micronutrient, physical and organoleptic properties of wheat-based bread. Nigerian Food Journal, 23: 59-68 
6. Eggleston, G., P. E. Omoaka and D. O. Ihedioha. 1993. Development and evaluation of products from cassava flour as new alternatives to wheaten breads. Journal of the Science of Food and Agriculture, 59: 377-385.

7. Giami, S. Y. 2005. Effects of heat processing on invitro protein digestibility and some chemical properties of African bread fruit (Treculia Africana decne) seed. Plant Food for Human Nutrition,56: 117-126.

8. Giami, S. Y.2004. Comparison of bread making properties of composite flour from kernels of roasted and boiled African breadfruit (Treculia Africana decne) seeds.Journal Raw Material Resources. 1: 1621.

9. Gisslen, W. 2012.Professional baking (6th ed.). New York: John Wiley

10. Hoseney, R. C., P. Wade and J. W. Finley. 1988. Soft wheat products. In Y. Pomeranz, Wheat: chemistry and technology (407-417). AACC St. Paul, MN, USA.

11. Ihekoronye, A. I., P. O. Ngoddy.1985. Integrated Food Science and Technology for the Tropics.Macmillan Publishers, New York.296-301.

12. Iwe, M. O., N. Michael., N. E. Madu., N. E. Obasi., G. I. Onwuka., T. U. Nwabueze., and J. O. Onuh. 2017. Physicochemical and Pasting Properties High Quality Cassava Flour (HQCF) and Wheat Flour Blends. Agrotechnology, 6(3): 1-8.

13. Mepba, H., L. Eboh and S. U. Nwaojigwa. 2007. Chemical composition, functional and baking properties of wheat-plantain composite flours. African Journal Food, Agriculture, Nutrition and Development, 7: 1-22.

14. Mohsenin, N. N. 1986. Friction Physical Properties of Plant and Animal Materials, Vol. 1Gordon and Breach Publishers, New York .556-642.

15. Ogazi, P. O., F. A. Oyewusi., A. U. Ozumba., H. O. Ogundipe., B. O. A. Osifo and F. A. Lukambi. 1996. Development and Sensory Evaluation of Soyamusa: A Soybean-Plantain Baby Food. International Conference on Banana and Plantain for Africa, ISHS ActaHortic. 540

16. Simmond, N.W. 1976. Food uses of Banana. Macmillan Publishers, Ibadan

17. Ukhum, M. E.1991. Production of instant plantain flour, sensory evaluation and physio-chemical changes during storage. Food Chemistry, 42(3): 287299. 